\title{
MORPHOMETRICS AND LENGTH-WEIGHT RELATIONSHIP IN THE BLUE SWIMMER CRAB, PORTUNUS PELAGICUS (LINNAEUS, 1758) (DECAPODA, BRACHYURA) FROM THE MANDAPAM COAST, INDIA
}

\author{
BY
}

JOSE JOSILEEN ${ }^{1}$ )

Central Marine Fisheries Research Institute, P.O. Box 1603, Cochin-682 018, India

\begin{abstract}
In this study, the interrelationships between various morphometric characters, viz., carapace width and length and chelar propodus length and height in males, as well as carapace width and length and abdominal width and length in females, were estimated using a total of 980 crabs, Portunus pelagicus. The carapace width/length - weight relationship was studied in both sexes on a total of 1188 crabs using the allometric growth equation of Von Bertalanffy. The allometric relationships between the characters of this set suggest that most relationships are positive and highly significant. The ' $b$ ' values for carapace width-weight in males and females were 3.607 and 3.293 , respectively, and for carapace length-weight they were 3.049 and 2.774 , respectively. The results show a significant deviation from an isometric growth pattern. An analysis of covariance indicates that there is a significant difference between sexes with respect to the carapace widthweight relationship.
\end{abstract}

\section{RÉSUMÉ}

Dans cette étude, les interrelations entre divers caractères morphométriques, viz., largeur et longueur de la carapace et longueur et hauteur du propodite de la pince chez les mâles, ainsi que la largeur et longueur de la carapace et largeur et longueur de l'abdomen chez les femelles, ont été estimés en mesurant un total de 980 crabes Portunus pelagicus. La relation taille de la carapace (largeur/longueur) versus poids a été étudiée dans les deux sexes sur un total de 1188 crabes en utilisant la courbe de croissance de Von Bertalanffy. Les relations allométriques entre ces caractères suggèrent que la plupart des interrelations sont positives et hautement significatives. Les valeurs de $\langle\mathrm{b} \gg$ pour la relation largeur de la carapace/poids chez les mâles et les femelles sont respectivement de 3,607 and 3,293, et pour la relation longueur de la carapace/poids de 3,049 et 2,774, respectivement. Les résultats montrent une déviation significative du modèle de croissance isométrique. Une analyse de covariance montre qu'il existe une différence significative entre les sexes au niveau de la relation largeur de la carapace/poids.

1) e-mail: drjoslin@gmail.com

(C) Koninklijke Brill NV, Leiden, 2011 


\section{INTRODUCTION}

Relatively little is known about the life history of the blue swimmer crab, Portunus pelagicus (Linnaeus, 1758), from Indian waters (Prasad \& Tampi, 1954; Jacob et al., 1990; Sukumaran \& Neelakantan, 1996, 1997; Josileen \& Menon, 2004, 2005). In crustaceans, as growth progresses, certain dimensions of the animal's body may grow much more than others, resulting in the phenomenon known as relative growth (Hartnoll, 1974). Studies of relative growth are often used to determine changes in the form and size of the abdomen, pleopods, or chelipeds during ontogeny. Knowledge of these distinguishing characters and size relationships in sexually mature individuals is of particular importance in the study of commercially valuable crustaceans. Such knowledge can be useful for further studies on the life history of the species and in the development of its fishery, resource management, and culture. The mathematical length-weight relationship thus yields information on the general well-being of individuals, variation in growth according to sex, size at first maturity, gonadal development, and breeding season. Study of the length-weight relationship in aquatic animals has wide application in delineating the growth patterns during their developmental pathways (Bagenal, 1978).

In population studies, morphometric analysis provides a powerful complement to genetic and environmental stock identification approaches (Cadrin, 2000) and length-weight relationships allow the conversion of growth-in-length equations to growth-in-weight for use in a stock assessment model (Moutopolos \& Stergiou, 2002). Information about individual body weight-length/width relationships in populations is important for estimating the population size of a stock, specifically for the purpose of its exploitation. The length-width/weight relationships are regarded as more suitable for evaluating crustacean populations (Phinney, 1977; Adegboye, 1981; Olmi \& Bishop, 1983; Suhalya \& Rashan, 1986; Prasad \& Neelakantan, 1988; Prasad et al., 1989; Sukumaran \& Neelakantan, 1997; Atar \& Sector, 2003; Gorce et al., 2006; Sangun et al., 2009).

The interrelationships between various morphometric characters, viz., carapace width/length and chelar propodus length/height in males, and carapace width/length and abdominal width/length in females were analysed and are here presented. The results will be useful in comparing the different stocks of the same species at different geographical locations.

\section{MATERIAL AND METHODS}

For the study, samples of Portunus pelagicus were collected from Mandapam, $\left(9^{\circ} 20-25^{\prime} \mathrm{N} 79^{\circ} 5-10^{\prime} \mathrm{E}\right)$, a major fishing centre for the blue swimmer crab, along 


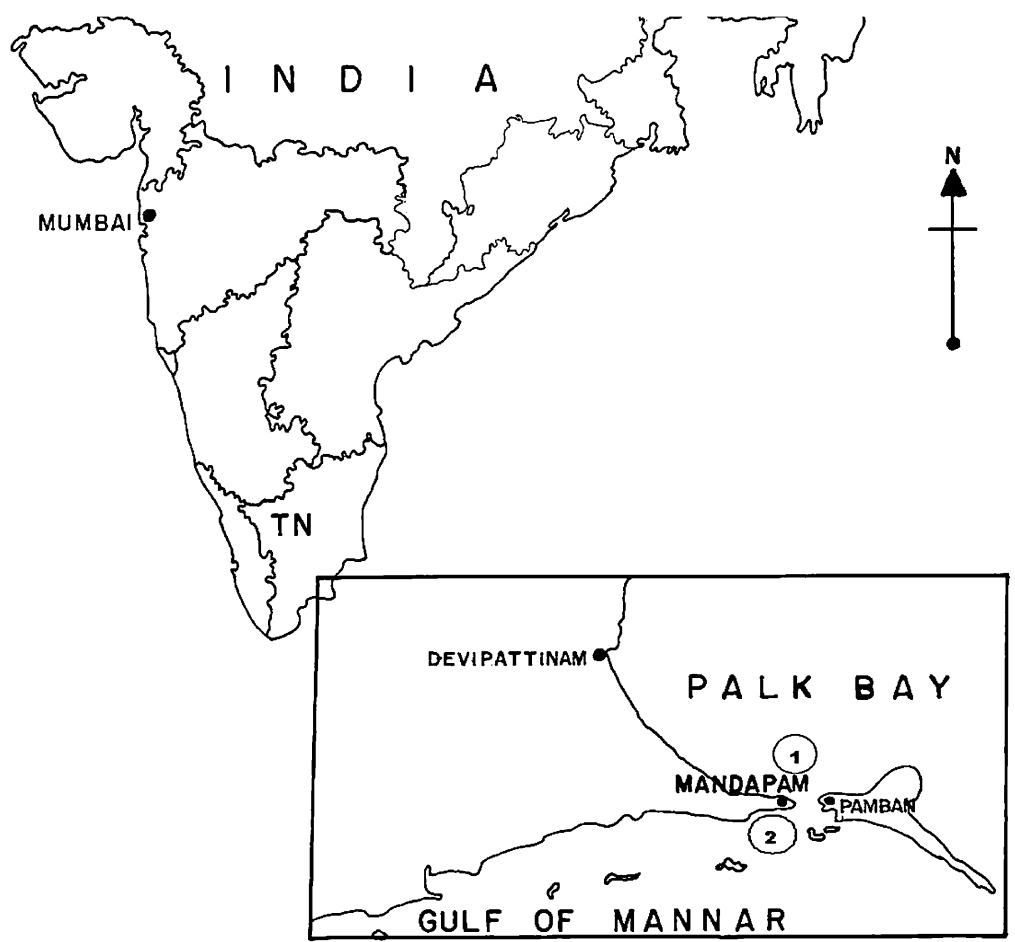

Fig. 1. Map showing the sampling stations of the study. TN, Tamil Nadu.

the south-east coast of India. The data used pertain to the trawl fishery, which was the major single gear used in the exploitation of the crabs, and was thus chosen as a basis for the analyses. An integration of the data of different types of gears was not attempted, as there was marked variation in the size composition of the catches. Fortnightly samples were taken from catches of trawlers from station 1 (Palk Bay) and station 2 (Gulf of Mannar) (fig. 1). Measurements were made for carapace width, carapace length, and total weight, separate for each sex. In addition, width and length of the abdomen were recorded for females, and chelar (propodus) length and height were taken for males. Vernier callipers with an accuracy of $0.5 \mathrm{~mm}$ were used for length measurements, and the total weight of the crab was determined to the nearest gram using a digital balance $(1 \mathrm{~g})$.

Carapace width $(\mathrm{CW})$ was taken as the distance between the tips of the posteriormost lateral carapace spines. Carapace length (CL) was measured dorsally along the midline, between the frontal notch and the posterior margin of the carapace. Right chelar propodus length (Ch L) was measured from the tip of the propodus' fixed finger to the base of the propodus. Propodus height $(\mathrm{Ch} \mathrm{H})$ of the same chela was measured across the widest region of the chelar palm. When the right chela was missing or damaged, the left chelar propodus length 

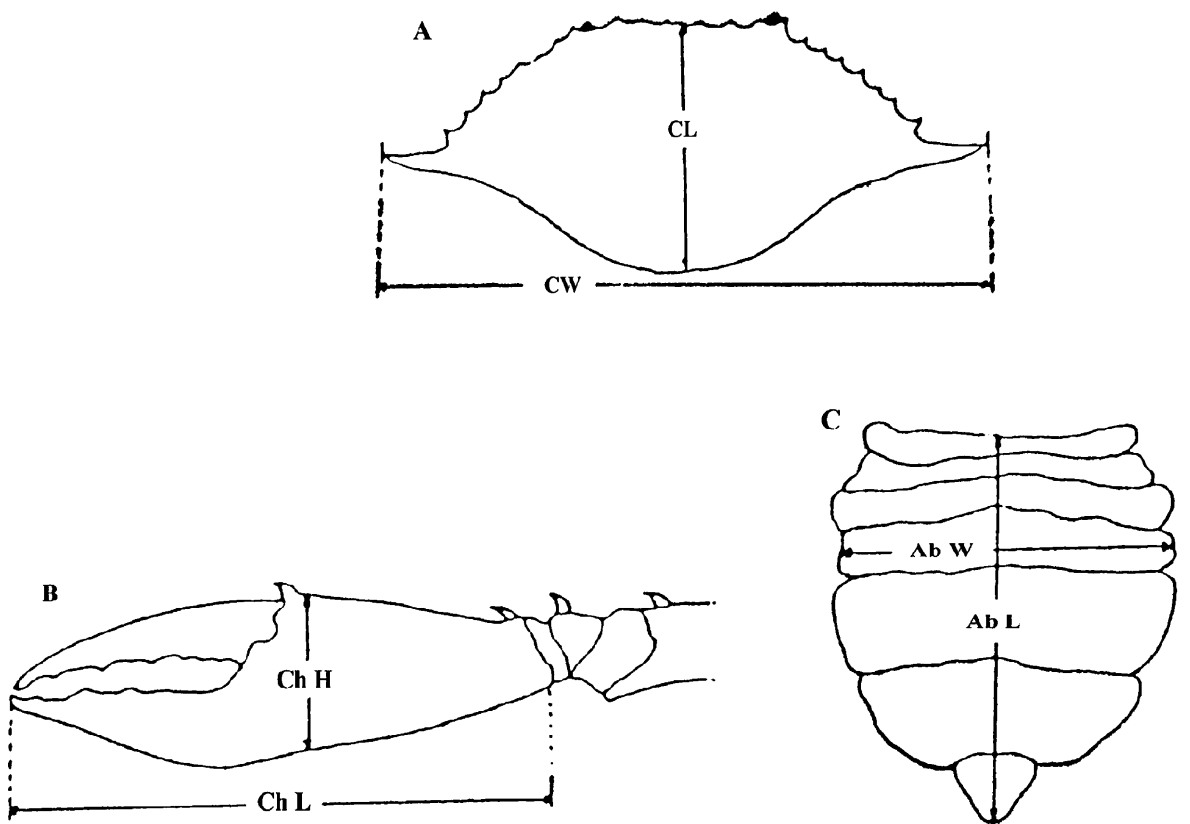

Fig. 2. The measurements used for morphometric studies in Portunus pelagicus (Linnaeus, 1758): A, carapace (dorsal view); B, chela; C, abdomen; CW, Carapace Width; CL, Carapace Length; Ch L, Chelar propodus Length; Ch H, Chelar propodus Height; Ab W, Abdominal Width; Ab L, Abdominal Length.

and height were taken, as in P. pelagicus both chelae are equally well developed. Abdominal width was measured at the maximum width, i.e., across the fourth somite. Abdominal length was measured along the midline from the anterior margin of the first somite to the posterior margin of the telson (fig. 2).

To study the interrelations between different morphometric characters in males, carapace length was regressed on chelar propodus length and chelar propodus height; carapace width was regressed on chelar propodus length and chelar propodus height; and chelar propodus length was regressed on chelar propodus height. In females, carapace width and length were regressed on abdominal length and width; and abdominal width was regressed on abdominal length. A total of 335 males and 645 females were used for the analyses.

Regression equations were calculated assuming an allometric growth equation $(Y=\mathrm{a}+\mathrm{b} X)$, to determine relations between different morphometric characters in males and females. The values of the correlation coefficient (r) were calculated to know the pattern of association between propodus/abdomen and carapace dimensions (Snedecor \& Cochran, 1967), with the objective of establishing a mathematical relationship between the variables, so that if one variable is known, the other could be computed approximately. 
Estimating carapace width-weight relationship

The carapace width-weight relationship was estimated using the log form of the allometric growth equation $\mathrm{W}=\mathrm{aL}^{\mathrm{b}}$ (Rickter, 1973), where $\mathrm{W}=$ expected weight, $\mathrm{L}=$ total carapace width, ' $\mathrm{a}$ ' $=y$-intercept or the initial growth coefficient, and 'b' = the slope or growth coefficient. The values of constants of ' $a$ ' and ' $b$ ' were calculated by the least squares method. The differences in the carapace width-weight relationship between sexes were tested by ANOVA (MS Excel). A total of 468 males and 720 females were used for the study.

\section{RESULTS AND DISCUSSION}

Interrelationships between different morphometric characters

Allometric equations with respect to males and females of Portunus pelagicus are indicated in tables I and II. The allometric relation between the set of characters studied suggested that in most cases the relationship was positive and highly significant (figs. 3-12).

\section{Relationship between carapace width and total weight}

The study has shown that females are marginally heavier than males up to 120$125 \mathrm{~mm}$ carapace width, and thereafter males are heavier than females. The results are given in table II.

The scatter diagram for males and females was obtained by plotting weight against carapace width/length of individual crabs (figs. 13-16). From the data presented, a distinct relationship was found between width and total weight, as judged from the closeness of the scatter dots, as well as from the parabolic nature of the plot.

\section{TABLE I}

Allometric equations and correlation coefficient ( $\mathrm{r}$ ) values between different variables in males of Portunus pelagicus (Linnaeus, 1758)

\begin{tabular}{llll}
\hline $\begin{array}{l}\text { Independent } \\
\text { variable }(x)\end{array}$ & $\begin{array}{l}\text { Dependent } \\
\text { variable }(y)\end{array}$ & $\begin{array}{l}\text { Allometric growth equation } \\
(y=\mathrm{a}+\mathrm{b} x)\end{array}$ & ' $\mathrm{r}^{2}$ ' value \\
\hline Carapace width & Chelar propodus length & $\mathrm{CPL}=-65.085+1.2079 \mathrm{CW}$ & $0.9249^{*}$ \\
Carapace width & Chelar propodus depth & $\mathrm{CPD}=-1.8734+0.1547 \mathrm{CW}$ & $0.3016^{*}$ \\
Carapace length & Chelar propodus length & $\mathrm{CPL}=-47.378+2.4352 \mathrm{CL}$ & $0.9316^{*}$ \\
Carapace length & Chelar propodus height & $\mathrm{CPD}=-0.2268+0.3227 \mathrm{CL}$ & $0.3142^{*}$ \\
Chelar propodus length & Chelar propodus height & $\mathrm{CPD}=6.7359+0.1255 \mathrm{CPL}$ & $0.3055^{*}$
\end{tabular}

* Indicates highly positive allometry, significant at $1 \%$ level. 


\section{TABLE II}

Allometric equations and correlation coefficient (r) values between different variables in females of Portunus pelagicus (Linnaeus, 1758)

\begin{tabular}{lllr}
\hline $\begin{array}{l}\text { Independent } \\
\text { variable }(x)\end{array}$ & $\begin{array}{l}\text { Dependent } \\
\text { variable }(y)\end{array}$ & $\begin{array}{l}\text { Allometric growth equation } \\
(y=\mathrm{a}+\mathrm{b} x)\end{array}$ & ' $\mathrm{r}^{2}$ 'value \\
\hline Carapace width & Abdomen width & $\mathrm{AW}=-21.058+0.4806 \mathrm{CW}$ & $0.8651^{*}$ \\
Carapace width & Abdomen length & $\mathrm{AL}=-13.511+0.4433 \mathrm{CW}$ & $0.8755^{*}$ \\
Carapace length & Abdomen width & $\mathrm{AW}=-14.274+0.9828 \mathrm{CL}$ & $0.8573^{*}$ \\
Carapace length & Abdomen length & $\mathrm{AL}=-7.8259+0.9139 \mathrm{CL}$ & $0.8675^{*}$ \\
Abdomen width & Abdomen length & $\mathrm{AL}=-4.9636+1.0550 \mathrm{AW}$ & $0.9128^{*}$ \\
\hline
\end{tabular}

*Indicates highly positive allometry, significant at $1 \%$ level.

The exponential values (b) for the carapace width-weight relationship in males and females (3.607 and 3.293, respectively) show that there is marked deviation from the isometric growth pattern. The ' $t$ ' test confirmed that ' $b$ ' significantly differs from 3 , in both sexes. The exponential values (b) for carapace length-weight in males and females (3.049 and 2.774, respectively) indicate that the significant departure from isometric growth is only evident in females. In males, the curve follows an isometric growth pattern. The ' $t$ ' values are given in table III.

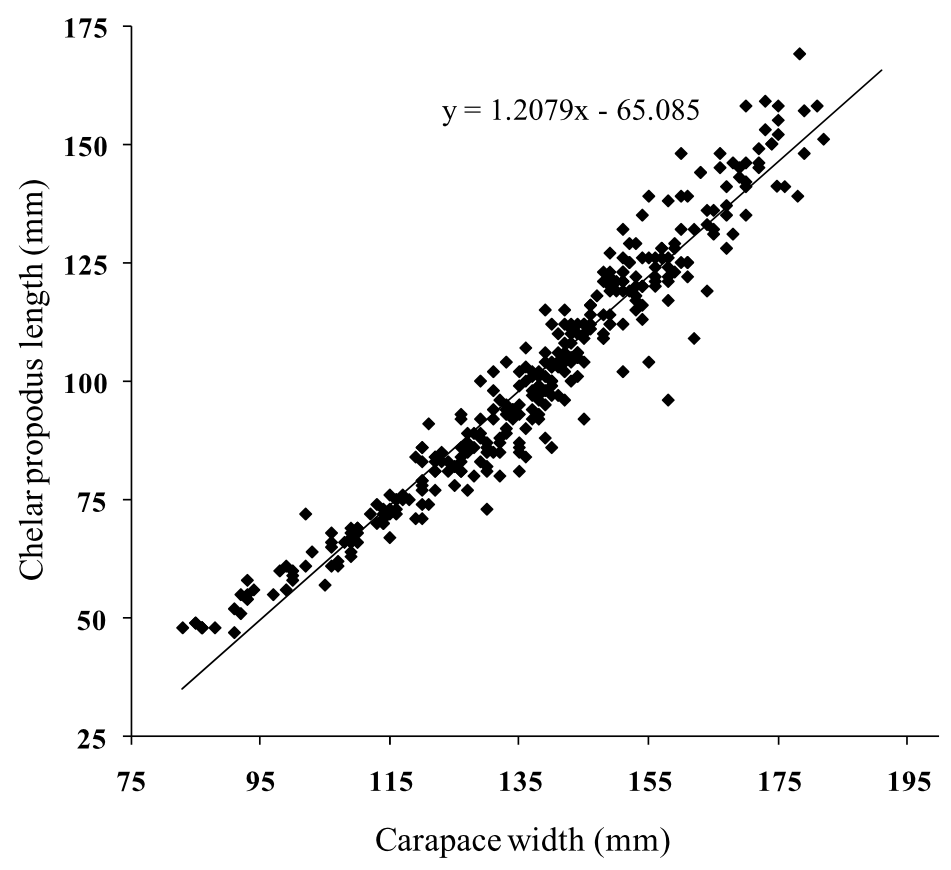

Fig. 3. Carapace width and chelar propodus length in males of Portunus pelagicus (Linnaeus, 1758). 


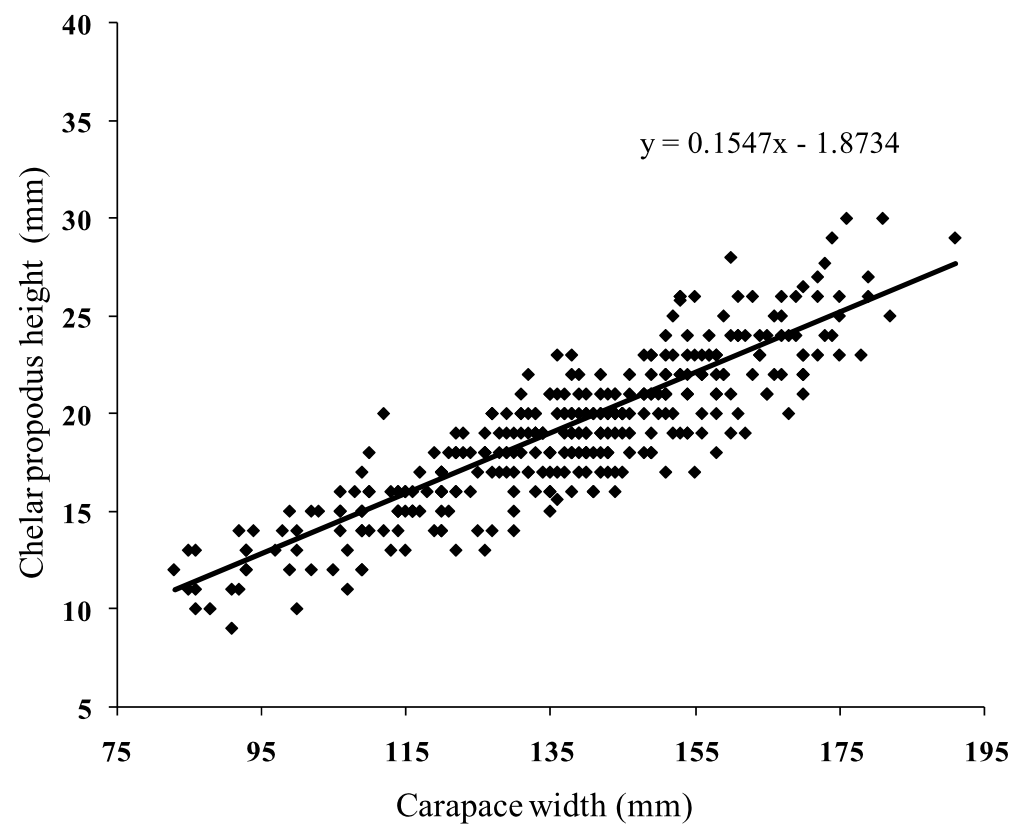

Fig. 4. Carapace width and chelar propodus height relationship in males of Portunus pelagicus (Linnaeus, 1758).

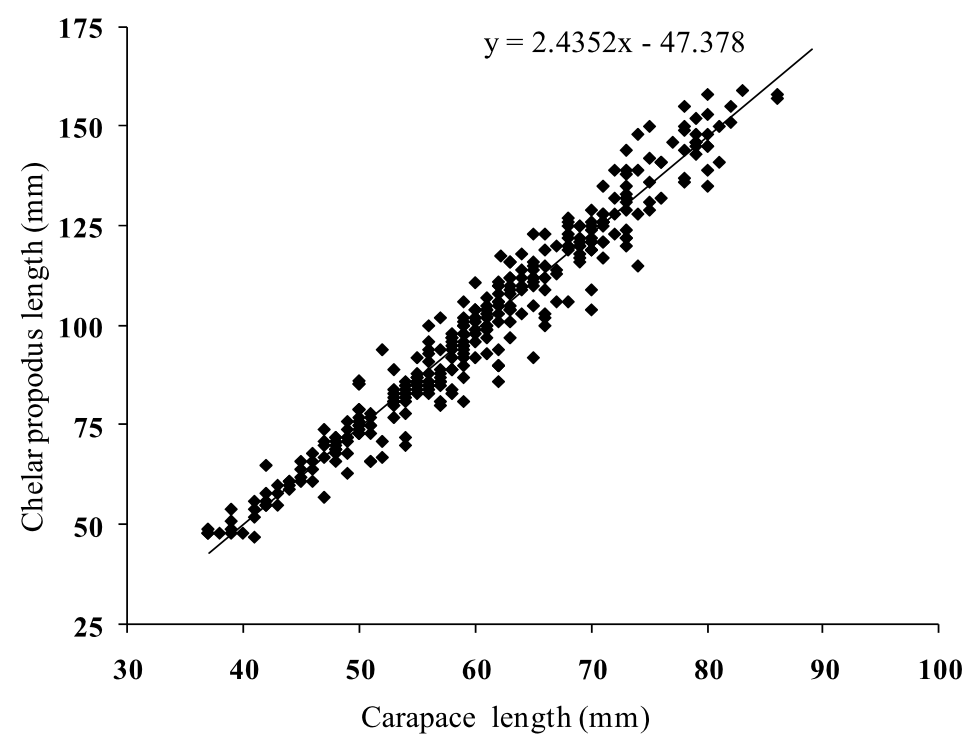

Fig. 5. Carapace length and chelar propodus length relationship in males of Portunus pelagicus (Linnaeus, 1758). 


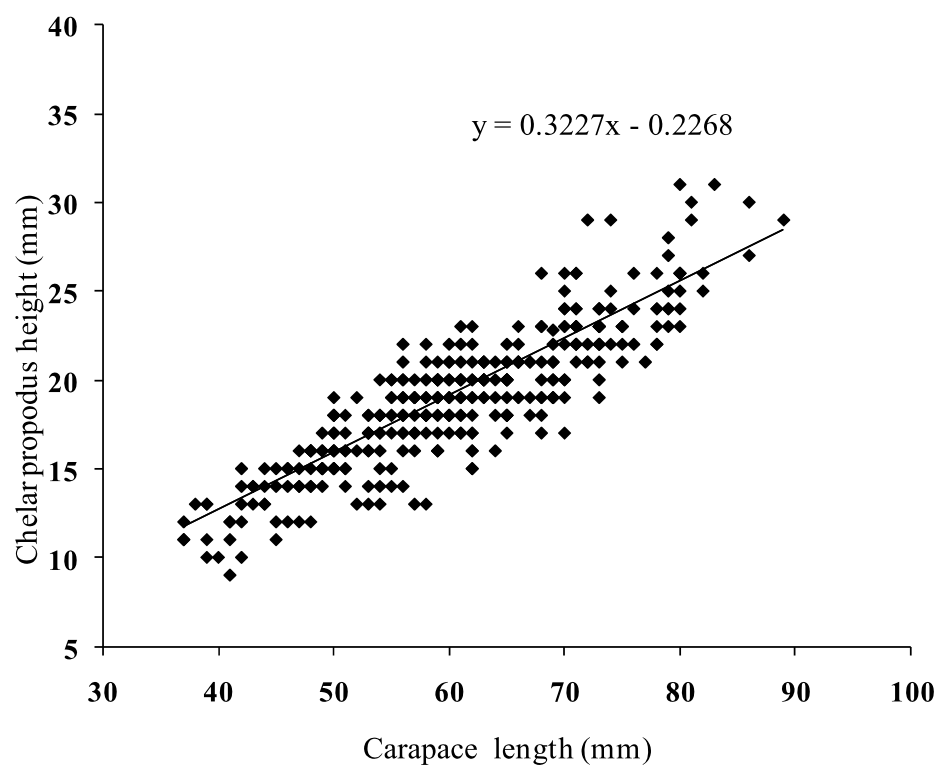

Fig. 6. Carapace length and chelar propodus height relationship in males of Portunus pelagicus (Linnaeus, 1758).

The results of the analyses of covariance (tables I and II) shows that the difference between slopes $(\mathrm{F}=23.15 ; P<0.01)$ and the difference between elevations $(\mathrm{F}=17.09 ; P<0.01)$ were both highly significant, indicating that

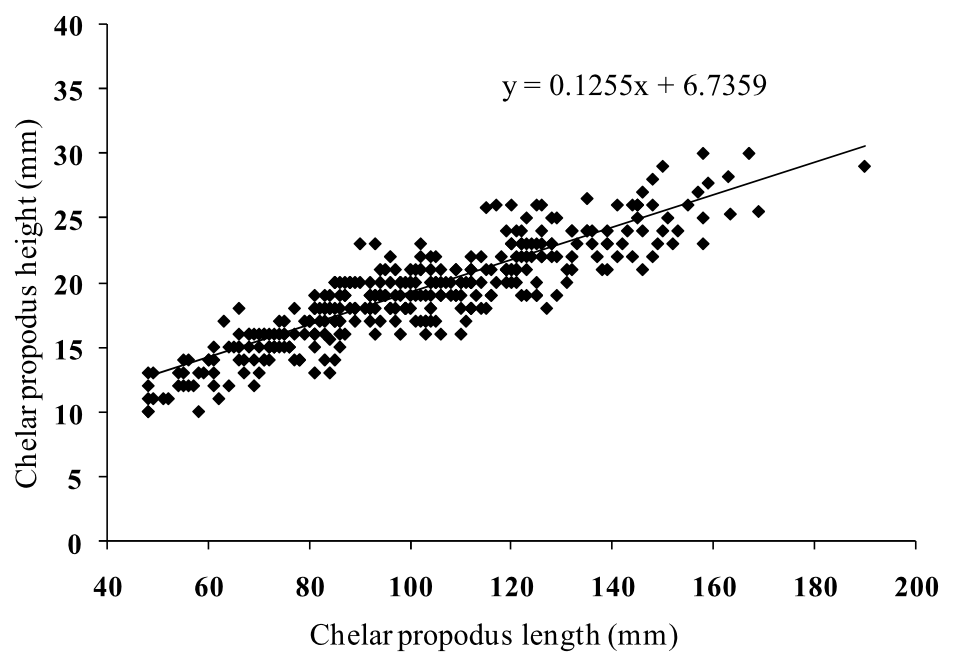

Fig. 7. Chelar propodus length and chelar propodus height relationship in males of Portunus pelagicus (Linnaeus, 1758). 


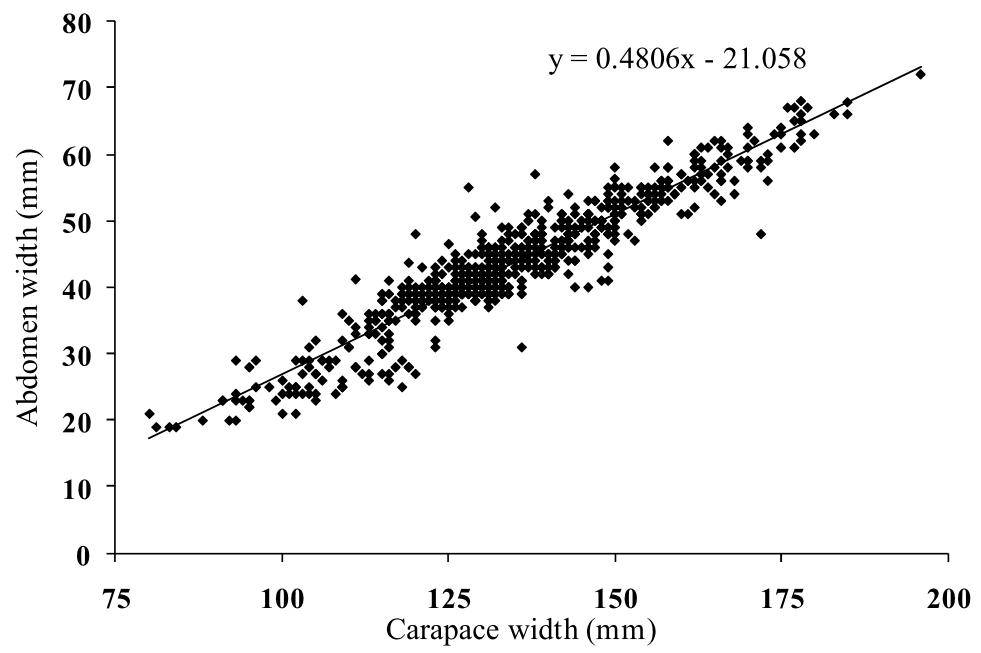

Fig. 8. Carapace width and abdomen width relationship in females of Portunus pelagicus (Linnaeus, 1758).

there is a significant difference between the sexes in respect to this carapace width-weight relationship. Likewise, also in the case of the carapace length-weight relationship a significant difference was found both between slopes $(\mathrm{F}=15.28$; $P<0.01)$ and between elevations $(\mathrm{F}=3.93 ; P<0.05)$.

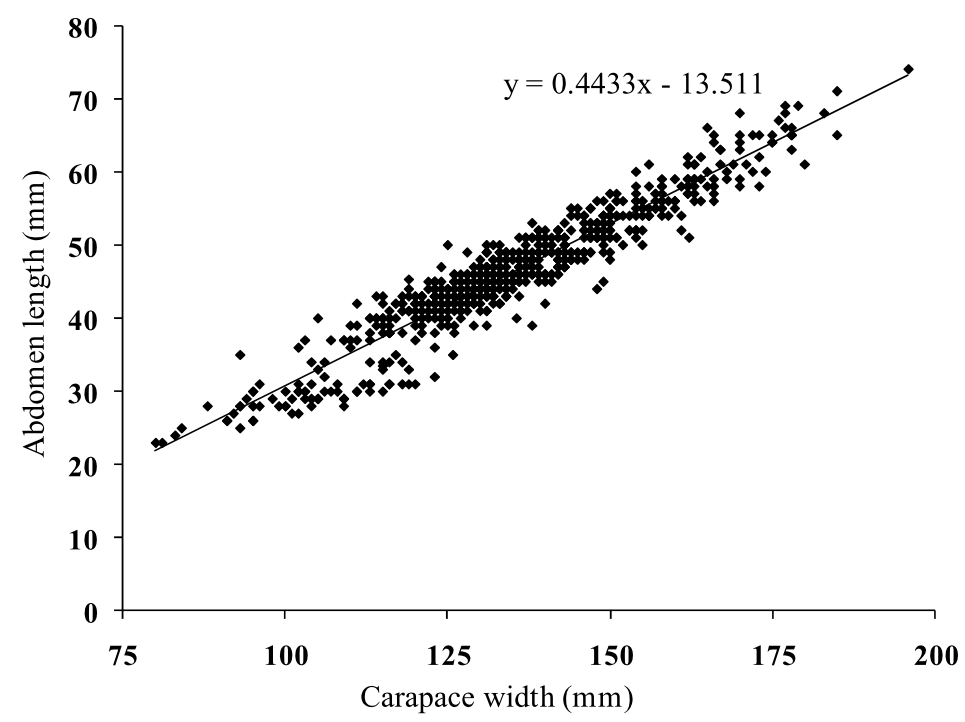

Fig. 9. Carapace width and abdomen length relationship in females of Portunus pelagicus (Linnaeus, 1758). 


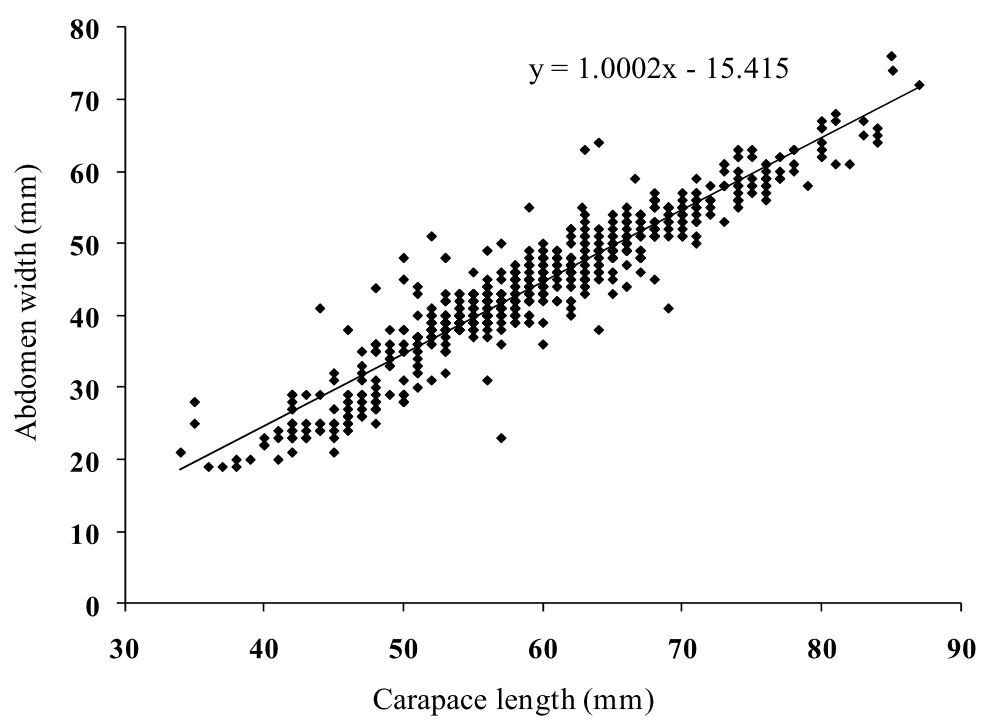

Fig. 10. Carapace length and abdomen width relationship in females of Portunus pelagicus (Linnaeus, 1758).

Knowledge of the distinguishing characteristics and size relations of sexually mature individuals is of particular importance in the study of commercially valuable crustaceans. Crabs of the family Portunidae are distinguished by having the dactylus of their fifth pereiopods enlarged and flattened, which facilitates swimming. In the Indo-Pacific region, the genus Portunus is represented by a

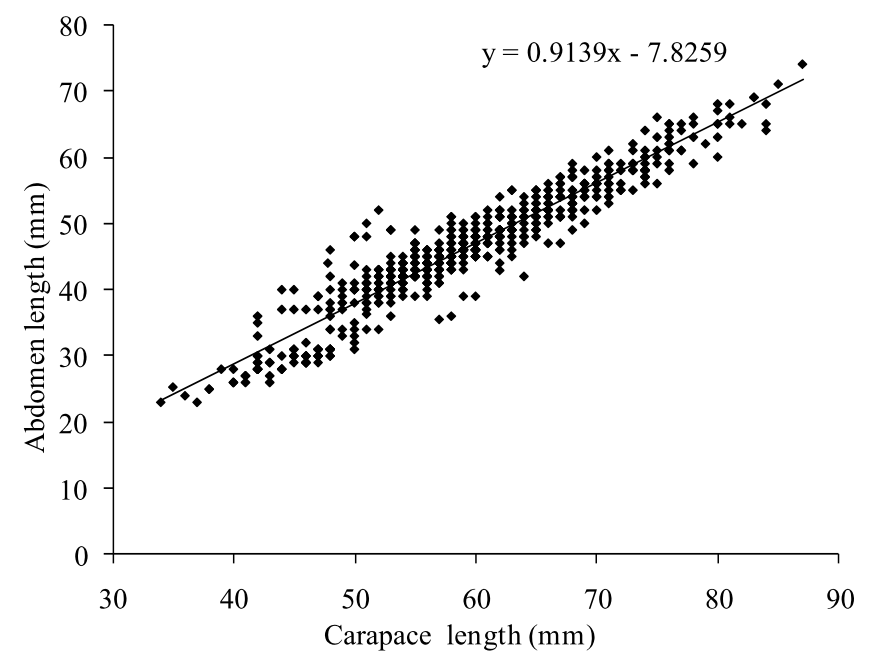

Fig. 11. Carapace length and abdomen length relationship in females of Portunus pelagicus (Linnaeus, 1758). 


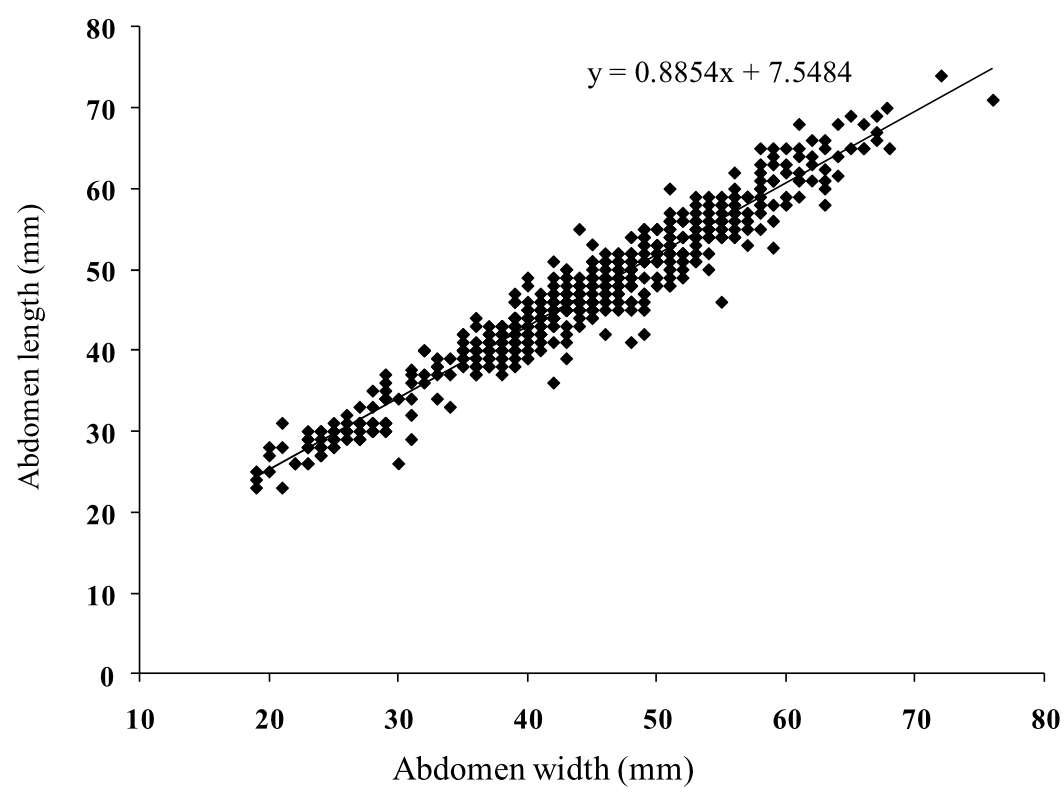

Fig. 12. Abdomen width and abdomen length relationship in females of Portunus pelagicus (Linnaeus, 1758).

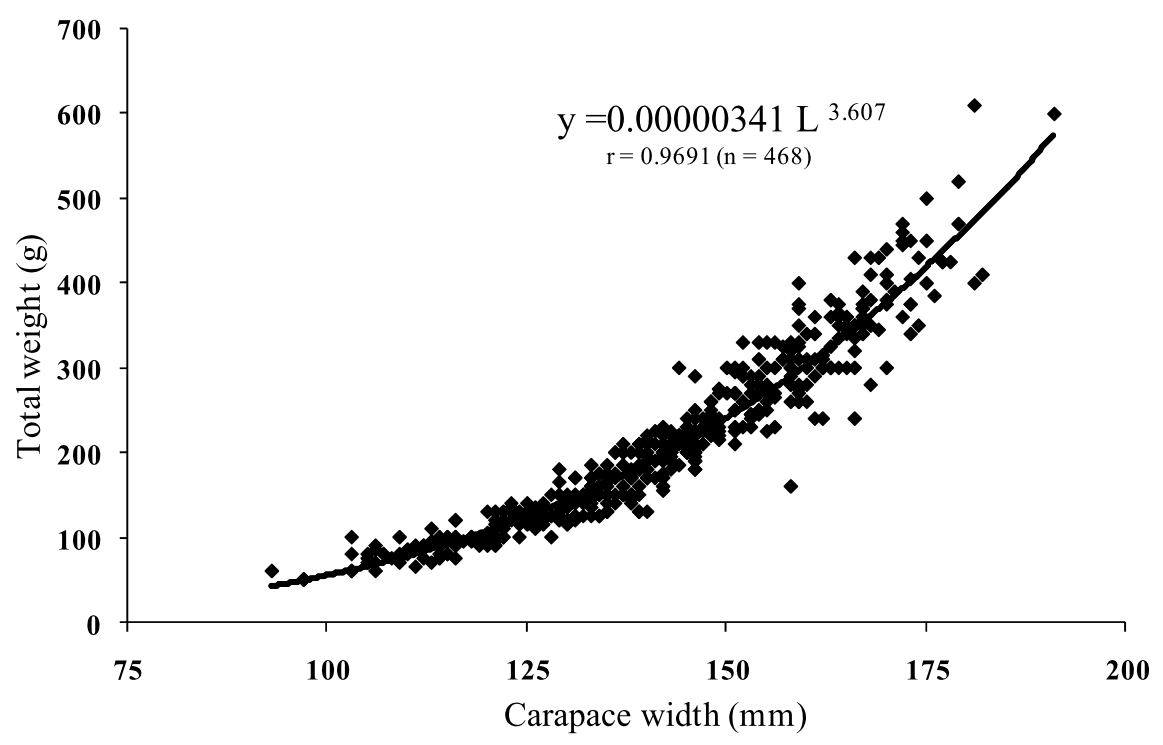

Fig. 13. Carapace width-weight relationship in male Portunus pelagicus (Linnaeus, 1758). 


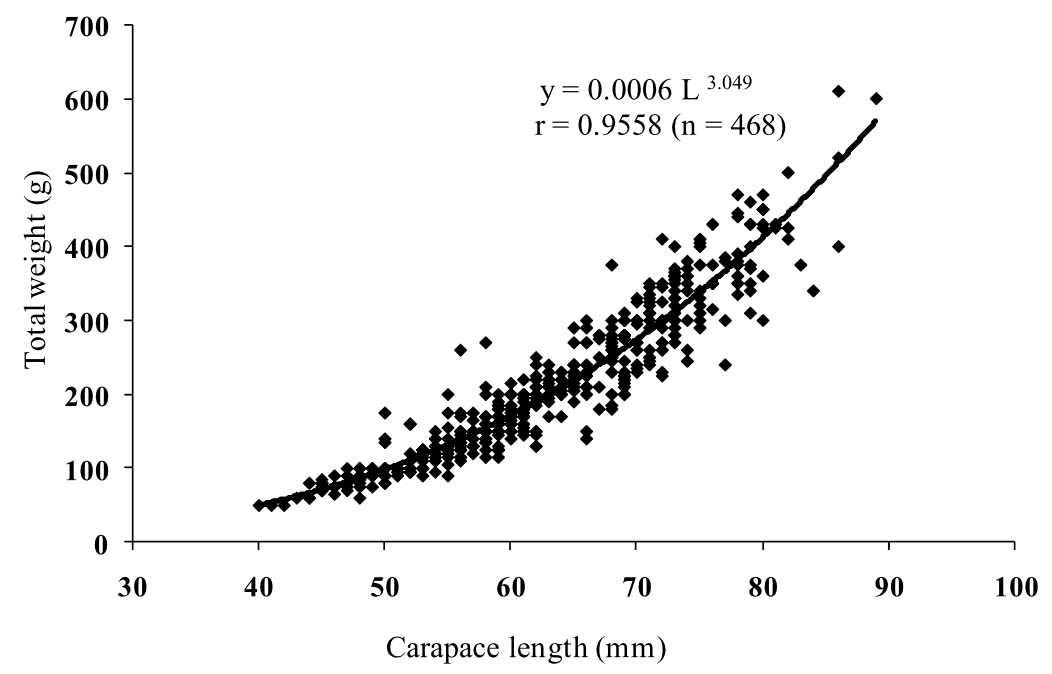

Fig. 14. Carapace length-weight relationship in male Portunus pelagicus (Linnaeus, 1758).

member that has nine antero-lateral spines at each side of the carapace, the posteriormost one of which is enlarged. All these characters are in agreement with the descriptions of Portunus pelagicus. In addition, in this species sexes are easily differentiated by the colour pattern of their exoskeleton. Males are brilliantly coloured with bright blue, and females have a dull brown colour. This unique feature is not seen in other common portunids. Gross morphological differences in external anatomy between sexes are similar to those of other portunid crabs

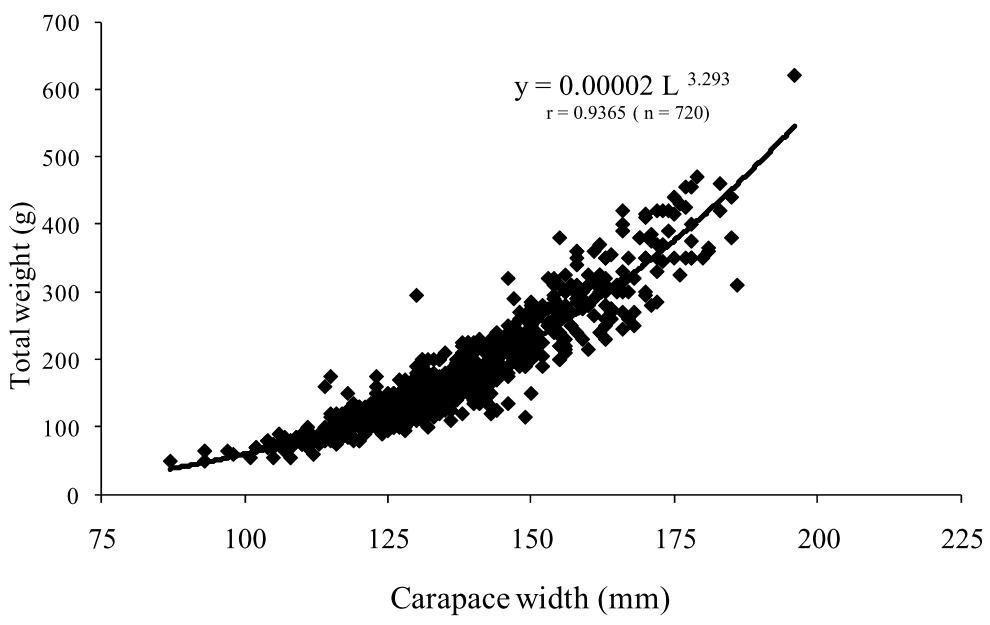

Fig. 15. Carapace width-weight relationship in female Portunus pelagicus (Linnaeus, 1758). 


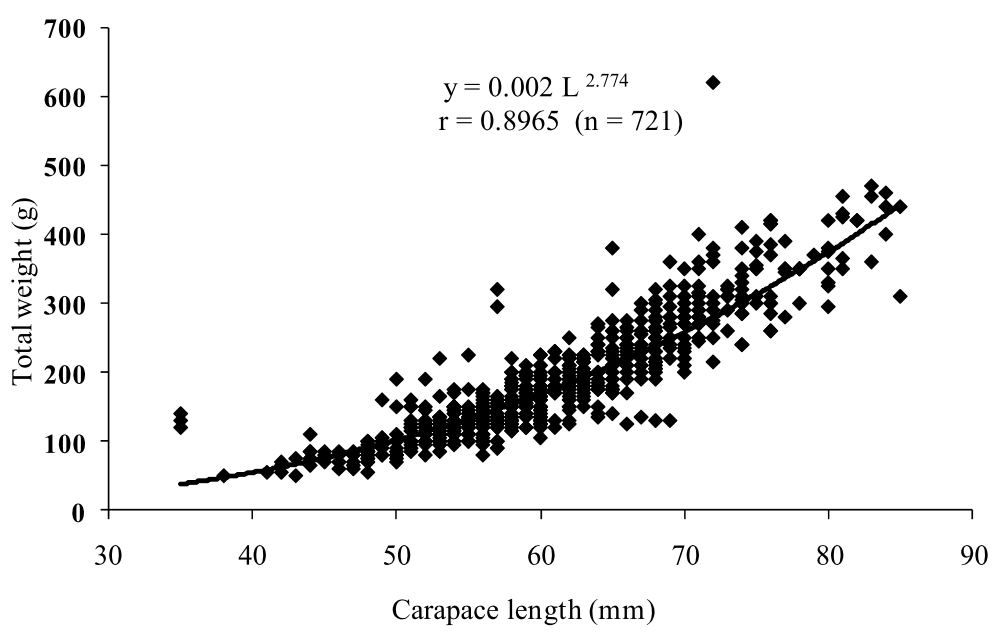

Fig. 16. Carapace length-weight relationship in female Portunus pelagicus (Linnaeus, 1758).

(George, 1963; Ryan, 1967; Johnson, 1980; Sumpton, 1990; Balasubramanian, 1993; Anil, 1997).

The allometric regression found describes changes in soft tissue content (or total animal weight for crustaceans) relative to carapace width/length. This result is consistent with general trends of scaling with body size in animals (Peters, 1983; Schmidt-Nielsen, 1984). In the present study, we did not examine any potential seasonal changes in carapace allometry and body weight, since a uniform climate (typical tropical-dry) prevailed in the area throughout the period of study.

The results of the length-weight relationship analysis in $P$. pelagicus indicate that in juveniles and pre-adult crabs, weight gain is almost uniform; females are slightly heavier than males until they attain 120-125 mm carapace width. Thereafter males are heavier than females at any given length. Sukumaran \& Neelakantan (1997) found a weight increase was evident above a carapace width of $115 \mathrm{~mm}$ in P. pelagicus. The tendency of males to be heavier than females in portunids is in accordance with the observations of Potter et al. (1983) in $P$. pelagicus, of Thomas (1984) in P. pelagicus and P. sanguinolentus (Herbst, 1783), from Cochin, of Sukumaran et al. (1986) in P. sanguinolentus from Mangalore, of Prasad et al. (1989) in P. sanguinolentus, P. pelagicus, and Scylla serrata (Forskål, 1775) from Karwar and of Sukumaran, and of Neelakantan (1997) in $P$. pelagicus and $P$. sanguinolentus from Mangalore. However, from the reports of these workers it is understood that there are marked variations in the results of carapace width-weight relationship in portunids from different places, and also within various regions of the same coast. In contrast to the result and reports of the above workers, Dhawan et al. (1976) found that females of P. pelagicus are heavier than males at a given length in Goan waters. 
TABLE III

Carapace width/length-total weight relationship in males and females of Portunus pelagicus (Linnaeus, 1758)

\begin{tabular}{|c|c|c|}
\hline Measurements & Logarithmic equation & Parabolic equation \\
\hline \multicolumn{3}{|l|}{ Male } \\
\hline Carapace Width-Total Weight & $\log =-12.589+3.607 \log \mathrm{L}$ & $\mathrm{W}=0.000003409 \mathrm{~L}^{3.607}$ \\
\hline Carapace Length-Total Weight & $\log =-7.339+3.049 \log \mathrm{L}$ & $\mathrm{W}=0.0006497 \mathrm{~L}^{3.049}$ \\
\hline \multicolumn{3}{|l|}{ Female } \\
\hline Carapace Width-Total Weight & $\log =-11.077+3.293 \log \mathrm{L}$ & $\mathrm{W}=0.00001546 \mathrm{~L}^{3.293}$ \\
\hline Carapace Length-Total Weight & $\log =-6.231+2.774 \log \mathrm{L}$ & $\mathrm{W}=0.001967 \mathrm{~L}^{2.774}$ \\
\hline \multicolumn{3}{|l|}{ Pooled } \\
\hline Carapace Width-Total Weight & $\log =-11.779+3.438 \log \mathrm{L}$ & $\mathrm{W}=0.000007664 \mathrm{~L}^{3.438}$ \\
\hline Carapace Length-Total Weight & $\log =-6.746+2.902 \log \mathrm{L}$ & $\mathrm{W}=0.001176 \mathrm{~L}^{2.902}$ \\
\hline
\end{tabular}

The exponential values (b) of the carapace width-weight relationship for males and females showed marked variation from the cube law, a marked departure from the isometric pattern of growth. In the case of carapace length-weight relationship, males followed an isometric growth pattern, while in females a significant deviation from isometric growth is evident. The results of the analysis of covariance indicated a significant difference between sexes with respect to carapace width/length-weight. The present findings are in accordance with those of Sukumaran and Neelakantan (1997) in P. pelagicus. The same author observed isometric growth in males and females of $P$. sanguinolentus.

Consequently, the results of the length/width-weight relationships presented here will enable crab biologists to derive length estimates for blue crabs that are weighed but not measured. Hence, the results of the study will make useful information, needed for the effective management and utilization of this resource in this area, where the blue swimmer crab occurs, such to make a good fishery possible.

\section{TABLE IV}

The ' $t$ ' values for the carapace width/length and total weight relationship in males and females of Portunus pelagicus (Linnaeus, 1758)

\begin{tabular}{lccl}
\hline Relationship & Sex & ' $t$ ' value & Remarks \\
\hline Carapace Width-Total Weight & Male & 14.29 & Significant at 1\% level \\
Carapace Width-Total Weight & Female & 6.39 & Significant at 1\% level \\
Carapace Length-Total Weight & Male & 1.29 & Not significant \\
Carapace Length-Total Weight & Female & 4.42 & Significant at 1\% level \\
\hline
\end{tabular}




\section{TABLE V}

ANOVA table for testing the equality of regression lines in the carapace width and total weight relationship among males and females of Portunus pelagicus (Linnaeus, 1758)

\begin{tabular}{lcccc}
\hline Source of variation & Degrees of freedom & Sum of squares & Mean square & Observed F \\
\hline $\begin{array}{l}\text { Deviation from individual } \\
\text { regression (within sexes) }\end{array}$ & 1188 & 25.546 & 0.02150 & \\
$\begin{array}{l}\text { Difference between } \\
\text { regressions }\end{array}$ & 1 & 0.489 & 0.48862 & $23.15^{* *}$ \\
$\begin{array}{l}\text { Deviation from average } \\
\text { regression }\end{array}$ & 1187 & 25.057 & 0.02110 & \\
$\begin{array}{l}\text { Differences between } \\
\text { corrected means }\end{array}$ & 1 & 0.367 & 0.36748 & $17.09^{* *}$ \\
\hline
\end{tabular}

** Significant at $1 \%$ level.

TABLE VI

ANOVA table for testing the equality of regression lines in the carapace length and total weight relationship among males and females of Portunus pelagicus (Linnaeus, 1758)

\begin{tabular}{lcccc}
\hline Source of variation & Degrees of freedom & Sum of squares & Mean square & Observed F \\
\hline $\begin{array}{l}\text { Deviation from individual } \\
\text { regression (within sexes) }\end{array}$ & 1188 & 39.202 & 0.033 & \\
$\begin{array}{l}\text { Difference between } \\
\text { regressions }\end{array}$ & 1 & 0.498 & 0.49839 & $15.28^{* *}$ \\
$\begin{array}{l}\text { Deviation from average } \\
\text { regression }\end{array}$ & 1187 & 38.704 & 0.03261 & \\
$\begin{array}{l}\text { Differences between } \\
\text { corrected means }\end{array}$ & 1 & 0.13 & 0.12955 & $3.93^{* *}$ \\
\hline
\end{tabular}

** Significant at $1 \%$ level.

\section{ACKNOWLEDGEMENTS}

I wish to express my sincere gratitude to the Director, Central Marine Fisheries Research Institute, Cochin, for his encouragements and providing the facilities for the research work. I am deeply indebted to Dr. J. C. von Vaupel Klein, the managing editor of Crustaceana, for editing this article.

\section{REFERENCES}

Adegboye, D., 1981. The "Cray fish Condition Factor": a tool in crayfish research. $5^{\text {th }}$ Int. Symp. on Freshwater Crayfish, Davis, CA (U.S.A.).

ANIL, M. K., 1997. Studies on the fishery and culture prospects of mud crabs (genus Scylla De Haan) along the Kerala coast: 1-213. (Ph.D. Thesis, Cochin University of Science and Technology, Cochin, India). 
ATAR, H. H. \& S. SECTOR, 2003. Width/length-weight relationships of the blue crab (Callinectes sapidus Rathbun, 1896) population living in Beymelek lagoon lake. Turkish Journ. vet. Anim. Sci., 27: 443-447.

BAGENAL, T., 1978. Method for assessment of fish production in fresh waters ( $3^{\text {rd }}$ ed.): $1-365$. (IBP Handbook, 3. Blackwell Scientific Publications, Oxford).

Balasubramanian, C. P., 1993. Studies on the deep water crab Charybdis (Goniohellenus) smithii MacLeay from the seas around India: 1-212. (Ph.D. Thesis, Cochin University of Science and Technology, Cochin, India).

CADRIN, S. X., 2000. Advances in morphometric identification of fishery stocks. Reviews in Fish Biology and Fisheries, 10: 91-112.

Dhawan, R. M., S. N. Dwivedi \& G. V. Rajamanickam, 1976. Ecology of the blue crab Portunus pelagicus (Linnaeus) and its potential fishery in Zuari estuary. Indian Journ. Fish., 23(1-2): 57-64.

George, M. J., 1963. The anatomy of the crab Neptunus sanguinolentus (Herbst). Part IV. Reproductive system and embryological studies. Journ. Madras Univ., (B) 33(3): 289-304.

Gorce, G., D. Erguden, L. Sangun, M. Cekic \& S. Alagoz, 2006. Width/length and relationships of the blue crab (Callinectes sapidus Rathbun, 1986) population living in Camlik Lagoon Lake (Yumurtalik). Pakistan Journ. biol. Sci., 9(8): 1460-1464.

HARTNOLL, R. G., 1974. Variation in growth pattern between some secondary sexual characteres in crabs (Decapoda, Brachyura). Crustaceana, 27: 131-136.

JACOB, R., P. N. PRASAD \& M. S. Kusuma, 1990. Maturity and dimensional studies in female crabs of Portunus sanguinolentus and P. pelagicus (Decapoda: Portunidae). Indian Journ. mar. Sci., 19: 221-223.

Johnson, P. T., 1980. The reproductive system. In: Histology of the blue crab, Callinectes sapidus — a model for the Decapoda: 327-367. (Praeger Special Studies).

Josileen, J. \& N. G. Menon, 2004. Larval stages of the blue swimmer crab, Portunus pelagicus (Linnaeus, 1758) (Decapoda, Brachyura). Crustaceana, 77(7): 785-803.

— — \& — , 2005. Growth of the blue swimmer crab, Portunus pelagicus (Linnaeus, 1758) (Decapoda, Brachyura) in captivity. Crustaceana, 78(1): 1-18.

Moutopoulos, D. K. \& K. I. Stergiou, 2002. Weight-length and length-length relationships for 40 fish species of the Aegean Sea (Hellas). Journ. appl. Ichthyol., 18: 200-203.

OLMI, E. J., III \& J. M. BISHOP, 1983. Total width-weight relationships of the blue crab Callinectes sapidus Rathbun from the Ashley River, South Carolina. Journ. Shellfish Res., 3: 99.

Peters, R. H., 1983. Cambridge studies in ecology: the ecological implications of body size: 1-329. (Cambridge University Press, New York).

Phinney, D. E., 1977. Length-weight relationships for the mature male snow crab, Chionocoetes bairdi. Fish. Bull. NMFS/NOAA, 75: 871-970.

Potter, I. C., P. J. Chrystal \& N. R. Loneragan, 1983. The biology of the blue manna crab Portunus pelagicus in an Australian estuary. Mar. Biol., Berlin, 78: 75-85.

Prasad, P. N. \& B. NeElakantan, 1988. Morphometry of the mud crab - Scylla serrata. Seafood Export Journ., 20(7): 19-22.

Prasad, P. N., J. Reeby, N. Kusuma \& B. Neelakantan, 1989. Width-weight and lengthweight relationship in three portunid crab species. Uttar Pradesh Journ. Zool., 9(1): 116-120.

RICKTER, W. E., 1973. Linear regressions in fisheries research. Journ. Fish. Res. Bd Canada, 30(3): 409-434.

RYAN, E. P., 1967. The morphometry of sexually mature instars in the crab, Portunus sanguinolentus (Herbst). Proc. Symp. Crustacea mar. biol. Ass. India, 2: 715-723.

Sangun, L., C. Tureli, E. AKAmCA \& O. DuYSAK, 2009. Width/length-weight and widthlength relationships for 8 crab species from north-Mediterranean coast of Turkey. Journal of Animal and Veterinary Advances, 8(1): 75-79. 
SCHMIDT-NiElSEN, K., 1984. Scaling — why is animal size so important?: 21-32. (Cambridge University Press, New York).

Snedecor, G. W. \& W. G. Cochran, 1967. Statistical methods applied to experiments in agriculture and biology: 1-534. (The Iowa State College Press, Ames, Iowa).

SuhalyA, A. D. \& L. J. RASHAN, 1986. Length-weight relationship of the crab Potamon magnum magnum Pretzmam. Current Science, 55(20): 1030-1031.

Sukumaran, K. K. \& B. NeElakantan, 1997. Length-weight relationship in two marine portunid crabs, Portunus (Portunus) sanguinolentus (Herbst) and Portunus (Portunus) pelagicus (Linnaeus) from the Karnataka coast. Indian Journ. mar. Sci., 26(1): 39-42.

Sukumaran, K. K., K. Y. Telang \& D. Thippeswamy, 1986. On the fishery and biology of the crab Portunus sanguinolentus (Herbst) along the south Kanara coast. Indian Journ. Fish., 33(2): 188-200.

SumPton, W. D., 1990. Morphometric growth and fisheries biology of the crab Charybis natator (Herbst) in Moreton Bay, Australia (Decapoda, Brachyura). Crustaceana, 59(2): 113-120.

Thomas, M., 1984. Studies on portunid crabs (Crustacea: Decapoda: Brachyura): 1-155. (Ph.D. Thesis, Department of Marine Sciences, University of Cochin, Cochin).

First received 4 March 2009.

Final version accepted 12 August 2011. 